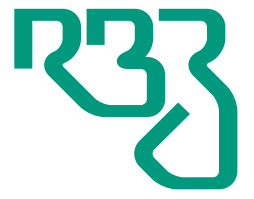

\section{Revista}

Brasileira de

Zootecnia

Brazilian Journal of Animal Science

ISSN 1806-9290

www.rbz.org.br

\title{
Effects of melanocortin 1 receptor $(M C 1 R)$ gene polymorphisms on plumage color in mule ducks
}

\author{
Yi-Chen Tu${ }^{1}$ (DD, Liang-Yuan Wei ${ }^{2}$, Yi-Ying Chang ${ }^{2}$ (DD, Hsiu-Chou Liu' ${ }^{2}$, \\ Hsien-Hsiung Lee ${ }^{1,3}$ (iD), Yu-Hsiang Yu ${ }^{1}$ (iD), Ming-Cheng Chen ${ }^{1^{*}}$ (iD) \\ ${ }^{1}$ National Ilan University, Department of Biotechnology and Animal Science, Yilan, Taiwan. \\ 2 Ilan Branch, Livestock Research Institute, Council of Agriculture, Yilan, Taiwan. \\ ${ }^{3}$ Visiting researcher at National Ilan University.
}

\begin{abstract}
*Corresponding author:
mcchen@niu.edu.tw

Received: August 3, 2018

Accepted: April 25, 2019

How to cite: Tu, Y.-C.; Wei, L.-Y.; Chang, Y.-Y.; Liu, H.-C.; Lee, H.-H.; Yu, Y.-H. and Chen, M.-C. 2019. Effects of melanocortin 1 receptor (MC1R) gene polymorphisms on plumage color in mule ducks. Revista Brasileira de Zootecnia 48:e20180180. https://doi.org/10.1590/rbz4820180180

Copyright: This is an open access article distributed under the terms of the

Creative Commons Attribution License (http://creativecommons.org/licenses/by/4.0/), which permits unrestricted use, distribution, and reproduction in any medium, provided the original work is properly cited.
\end{abstract}

ABSTRACT - The objective of the present study was to investigate the effect of single nucleotide polymorphism (SNP) of the melanocortin 1 receptor $(M C 1 R)$ gene on plumage coloration in mule ducks. PCR-high-resolution melting analysis (PCR-HRM) and DNA sequencing were used to identify the SNP variability of the $M C 1 R$ gene in white common ducks. Three non-synonymous SNP $(M C 1 R$ gene exon 1, c.52G $>\mathrm{A}$, c.376G $>\mathrm{A}$, and c.409G $>A$ ) were identified in white Tsaiya ducks. Mating test (white Tsaiya ducks $\times$ white Muscovy drakes) in combination with polymerase chain reaction-restriction fragment length polymorphism (PCR-RFLP) was performed to investigate the effect of non-synonymous SNP of different maternal lines on plumage coloration in mule ducks. Genotyping results from 58 white Tsaiya ducks revealed the significant associations between genetic variations (c.52G>A, c.376A $>\mathrm{G}$, and c.409G $>\mathrm{A}$ ) and plumage color in two maternal populations. After genotyping of 266 mule ducks, these three non-synonymous SNP identified in white Tsaiya ducks were significantly associated with plumage color of mule ducks. Therefore, the polymorphisms of $M C 1 R$ gene at $c .52 \mathrm{G}>\mathrm{A}, \mathrm{c} .376 \mathrm{~A}>\mathrm{G}$, and c. $409 \mathrm{G}>\mathrm{A}$ in white Tsaiya duck could be used in marker-assisted selection to improve the plumage color of mule ducks.

Keywords: Muscovy drakes, polymerase chain reaction-restriction fragment length polymorphism, single nucleotide polymorphism, Tsaiya ducks

\section{Introduction}

Animal coat and plumage color are determined by the pigment distribution or proportion of eumelanin and pheomelanin (Prota, 1980). The content of eumelanin and pheomelanin is regulated by the melanocortin 1 receptor-mediated melanogenesis pathway (Schiöth et al., 2003). Melanocortin 1 receptor, encoded by the $M C 1 R$ gene, is a G protein-coupled receptor that is mainly expressed in melanocytes (Ollmann et al., 1998). Melanocortin 1 receptor is activated by the binding of $\alpha$-melanocyte stimulating hormone ( $\alpha-\mathrm{MSH})$, which triggers eumelanin biosynthesis (Mundy, 2005). Constitutively active melanocortin 1 receptor caused by dominant gene mutation is highly correlated with black color, while recessive mutation of $M C 1 R$ gene leads to a red or yellow phenotype in animals (Klungland et al., 1995; Marklund et al., 1996; Everts et al., 2000; Newton et al., 2000; Kerje et al., 2003).

Mule ducks are sterile intergeneric hybrids that are produced by crossing female common ducks (Anas platyrhynchos) with Muscovy drakes (Cairina moschata). The mule duck is a major meat-type duck in Taiwan, and white feather color has economic advantages over black feather color because of consumer 
preference. Therefore, selection of mule ducks with white plumage by breeding is still an unmet need. Since mule ducks are an infertile hybrid, selection approaches have to be performed on parental lines.

Over the past decade, traditional selection of maternal lines of mule duck, including Tsaiya and Pekin ducks, have successfully improved mule ducks whose white plumage is generally accepted by consumers in Taiwan. Many studies have demonstrated the polymorphisms of genes involved in the melanogenesis pathway associated with plumage coloration between avian species (Hoque et al., 2013; Zhang et al., 2015; Ran et al., 2016; Sultana et al., 2017; Sultana et al., 2018). However, little is known about the relationship between gene polymorphism and plumage coloration in intergeneric hybrids.

It has been demonstrated that the several polymorphisms of genes involved in the melanocortin 1 receptor-mediated melanogenesis pathway, such as melanogenesis-associated transcription factor and dopachrome tautomerase (DCT), have an influence on plumage color in Asian duck breeds (Sultana et al., 2018). However, the single nucleotide polymorphism (SNP) variations of TYP gene (tyrosinase), a rate-limiting enzyme in the production of melanin pigment, are not associated with plumage color in Cherry Valley and Liancheng white hybrid ducks (Zhang et al., 2015).

It has been reported that exon 1 of $M C 1 R$ gene contributes to plumage coloration in Magelang ducks (Rahayu et al., 2015). Previous studies all focused on the effect of polymorphisms of gene involved in melanogenesis pathway on plumage color in different breeds of common ducks (Anas platyrhynchos) (Zhang et al., 2015; Rahayu et al., 2015; Sultana et al., 2018). However, the potential association between the $M C 1 R$ gene and plumage color phenotypes in intergeneric hybrids, such as mule ducks, has not been validated. Therefore, the objective of the current study was to analyze the association between the polymorphisms of the $M C 1 R$ gene and plumage color in mule ducks.

\section{Material and Methods}

Research on animals was conducted according to the institutional committee on animal use (IACUC case No. LRIIL IACUP 105002 and 106004). All experiments were conducted in Yilan, Taiwan (latitude $24^{\circ} 46^{\prime} 00^{\prime \prime} \mathrm{N}$, longitude $121^{\circ} 45^{\prime} 00^{\prime \prime} \mathrm{E}$, and $7.38 \mathrm{~m}$ altitude). The experimental period was carried out from September 1, 2015 to Jully 1, 2017.

Thirty-nine female white Tsaiya ducks (Anas platyrhynchos) from a conservation population (the 18th generation of a natural mating program without selection) and nineteen female white Tsaiya ducks from a selection population (30th generation of a plumage color selection program using traditional phenotype-based estimated breeding) were mated by artificial insemination with pooled semen from three white Muscovy drakes (Cairina moschata) (Figure 1).

The plumage color of intergeneric hybrid ducks, mule ducks, was graded based on the area of black spots on the head and back (Figure 2): 1 to 3 indicates ducks with black spot on head; 4 to 7 indicates ducks with a black head and a little spot on back; 8 to 10 indicates ducks with black head, black back, and black tail; and 11 to 15 indicates ducks with a mottled to pure black coat (Lee and Kang, 1997).

Venous blood samples were collected from the maternal line (58 white Tsaiya ducks) and intergeneric hybrid ducks (266 mule ducks). The genomic DNA was extracted from blood using a standard phenol/chloroform method, and the concentration of purified DNA was measured by a spectrophotometer (NanoVue PlusTM, GE Healthcare, UK). Stock DNA samples were then stored at $-20{ }^{\circ} \mathrm{C}$ for analysis of genetic polymorphisms of MC1R gene.

Blood samples from five white Tsaiya ducks of conservation population were subjected to genomic DNA extraction. For detection of potential SNP, three primer pairs targeting exon 1 of the $M C 1 R$ gene were evaluated using the HRM (high-resolution melting) assay (Table 1). Primers were designed based on the genome sequence of exon 1 of $M C 1 R$ from Pekin duck (NCBI Reference Sequence: NW_004676862) using the Vector NTI 9.1 (Thermo Fisher Scientific, Waltham, MA, USA) software. Polymerase chain reaction (PCR) was performed by G-Storm GS4 Thermal Cycler (GRI, Rayne, UK) and One TaqTM polymerase (New England BioLabs, Beverly, MA, USA). The PCR cycle was pre-denaturation at $95{ }^{\circ} \mathrm{C}$ 


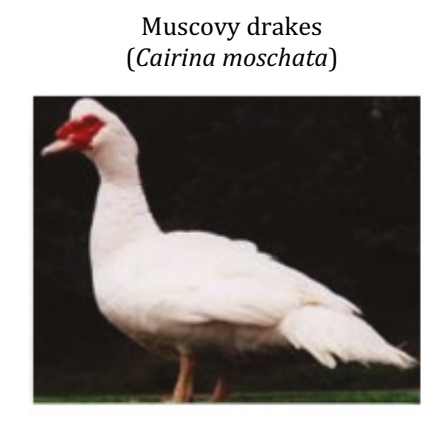

Conserved Tsaiya ducks

or

Selected Tsaiya ducks

(Anas platyrhynchos)
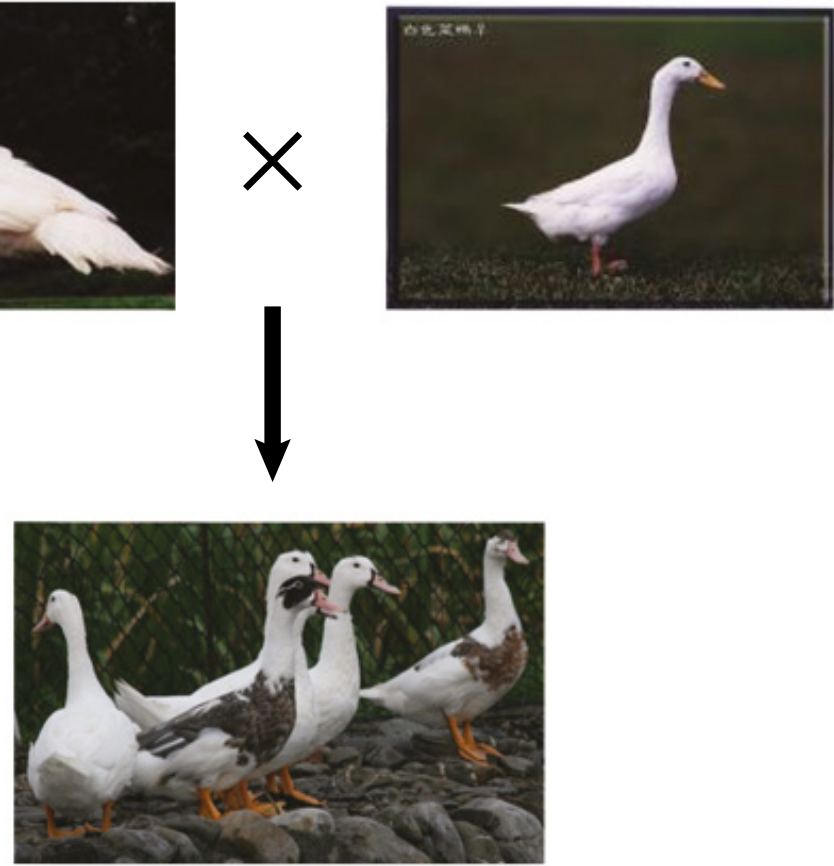

Mule ducks

For examination of the association between the polymorphisms of the $M C 1 R$ gene and plumage color in mule ducks, female white Tsaiya ducks (Anas platyrhynchos) from a conservation population or female white Tsaiya ducks from a selection population are mated by artificial insemination with pooled semen from white Muscovy drakes (Cairina moschata).

Figure 1 - Illustration of the mating test.

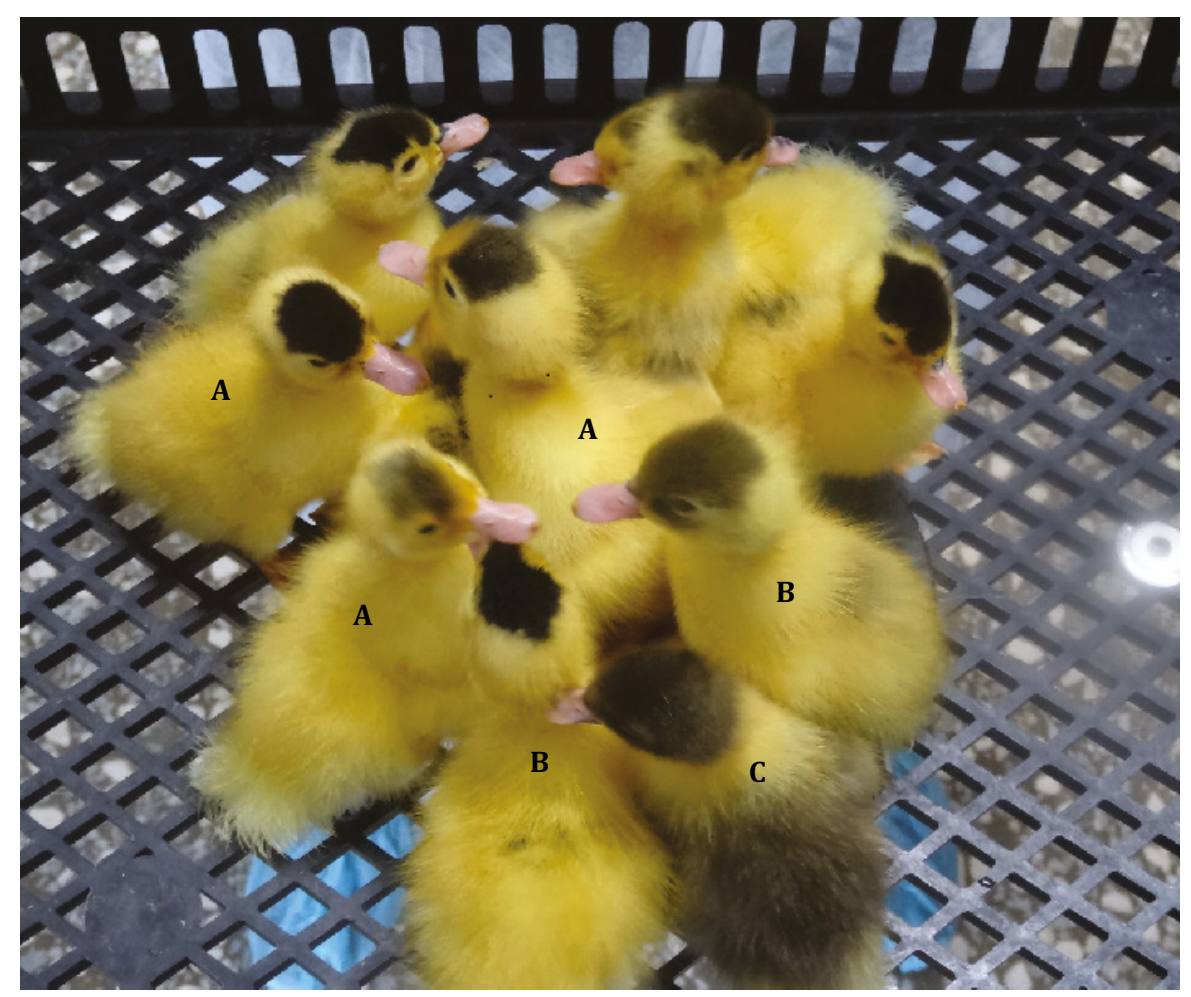

A indicates grade 1-3, B indicates grade 4-7, and C indicates grade 11-15.

Figure 2 - Plumage color grading in mule ducks. 
Table 1 - Primer and restriction enzymes for detection of $M C 1 R$ gene polymorphism by HRM, sequencing and PCR-RFLP

\begin{tabular}{|c|c|c|c|c|c|c|}
\hline $\begin{array}{l}\text { cDNA } \\
\text { position }^{1}\end{array}$ & Primer sequence $\left(5^{\prime} \rightarrow 3^{\prime}\right)$ & $\begin{array}{l}\text { Annealing } \\
\text { temperature }\end{array}$ & $\begin{array}{l}\text { Product } \\
\text { size }\end{array}$ & Polymorphism & $\begin{array}{c}\text { Restriction } \\
\text { enzyme }\end{array}$ & Allele size \\
\hline $52 \mathrm{~F}$ & TGCTC CGTGA GCCCT GGAAC GCCAT C & \multirow{2}{*}{$55.0^{\circ} \mathrm{C}$} & \multirow{2}{*}{$250 \mathrm{bp}$} & \multirow{2}{*}{$\mathrm{G} \rightarrow \mathrm{A}$} & \multirow{2}{*}{$T a q^{\alpha}-\mathrm{I}$} & A: 168 bp, 82 bp \\
\hline $52 \mathrm{R}$ & TCCGC CAGGT TGCTG ACGCT & & & & & G: 168 bp, 57 bp, 25 bp \\
\hline $376 \mathrm{~F}$ & ATCCA CGCCA GCATC ATC & \multirow{2}{*}{$56.4^{\circ} \mathrm{C}$} & \multirow{2}{*}{$106 \mathrm{bp}$} & \multirow{2}{*}{$\mathrm{G} \rightarrow \mathrm{A}$} & \multirow{2}{*}{$B c c-\mathrm{I}$} & G: $106 \mathrm{bp}$ \\
\hline $376 \mathrm{R}$ & AGCGG TCCAC GGCGA TCA & & & & & A: 67 bp, 39 bp \\
\hline $409 \mathrm{~F}$ & GACGC TCTTC ATGCT GCTGA TG & \multirow{2}{*}{$63.4^{\circ} \mathrm{C}$} & \multirow{2}{*}{$400 \mathrm{bp}$} & \multirow{2}{*}{$\mathrm{G} \rightarrow \mathrm{A}$} & \multirow{2}{*}{$B c l-\mathrm{I}$} & G: $400 \mathrm{bp}$ \\
\hline $409 \mathrm{R}$ & GTGCT TCTGC TGGCT GGAGA TG & & & & & A: 271 bp, 129 bp \\
\hline
\end{tabular}

${ }^{1} \mathrm{~F}=$ forward primer; $\mathrm{R}=$ reverse primer.

for $5 \mathrm{~min}$, denaturation at $95^{\circ} \mathrm{C}$ for $30 \mathrm{~s}$, annealing at $55-63.4{ }^{\circ} \mathrm{C}$ for $30 \mathrm{~s}$, elongation at $72{ }^{\circ} \mathrm{C}$ for $30 \mathrm{~s}$, and post-elongation at $72^{\circ} \mathrm{C}$ for $7 \mathrm{~min}$ and then a 35-cycle replication. The amplified cDNA was melted in a high-resolution melting device (HR-1 instrument, Idaho Technology, Salt Lake City, UT, USA) using LCGreen Plus + Melting Dye (Idaho Technology, Salt Lake City, UT, USA). High resolution melting curve acquisition was performed from 40 to $95{ }^{\circ} \mathrm{C}$ in $0.2^{\circ} \mathrm{C}$ increments for $1 \mathrm{~s}$ and then normalized by the LightScanner Software with CALL-IT 2.0 (Idaho Technology, Salt Lake City, UT, USA).

Potential variations in the $M C 1 R$ gene determined by HRM analysis were further sequenced. We performed the PCR using a SelectCycler II Thermal Cycler (Select BioProducts, Edison, NJ, USA) and One TaqTM polymerase (New England BioLabs, Beverly, MA, USA). The PCR cycle was pre-denaturation at $95^{\circ} \mathrm{C}$ for $5 \mathrm{~min}$, denaturation at $95^{\circ} \mathrm{C}$ for $30 \mathrm{~s}$, annealing at $55-63.4{ }^{\circ} \mathrm{C}$ for $30 \mathrm{~s}$, elongation at $72{ }^{\circ} \mathrm{C}$ for $35 \mathrm{~s}$, and post-elongation at $72^{\circ} \mathrm{C}$ for $7 \mathrm{~min}$ and then a 35 -cycle replication. The PCR product was purified using a QIAquick PCR Purification Kit (Qiagen, Valencia, CA, USA) and sequenced with ABI Prism 3700 DNA sequencer (Applied Biosystems). Sequences were analyzed using the AlignX software (Thermo Fisher Scientific, Waltham, MA, USA) to identify potential polymorphisms. The PCR-RFLP analysis was used for genotyping each SNP of the MC1R gene coding regions in white Tsaiya ducks and mule ducks (Table 1). The enzymatic reactions were performed in $10 \mu \mathrm{L}$ reaction mixtures containing $8 \mu \mathrm{L}$ of PCR products, two units of each restriction enzyme and reaction buffer. The digested products were separated by $3 \%$ agarose gel electrophoresis and then visualized with ethidium bromide.

Each duck formed an experimental unit. Chi-square test $\left(\chi^{2}\right)$ was used to determine a significant difference in potential associations between MC1R SNP and plumage color using SAS software (Statistical Analysis System, version 9.2).

The statistical model applied for the genotypic and SNP analysis of $M C 1 R$ was:

$$
\chi^{2}=\Sigma \frac{(\mathrm{o}-e)^{2}}{e} \text { with degrees of freedom }(\mathrm{r}-1) \times(\mathrm{c}-1)
$$

in which $o=$ observed frequency of genotype and SNP, $e=$ expected frequency of genotype and SNP, $r=$ number of rows of the contingency table, and $c=$ columns of the contingency table. The degrees of freedom are the number of values in the final calculation of a statistical model that are free to vary.

Chi-square test of independence was performed following null and alternative hypotheses, $\mathrm{HO}$ (independent, no association) and H1 (not independent, association), respectively. The decision is to reject the $\mathrm{HO}$ (and infer the alternative hypothesis) if the calculated value is greater than the critical value. P-values of less than 0.05 were considered statistically significant.

Haploview software (Barrett et al., 2005) was used to calculate haplotype numbers and their frequencies among three SNP from the five duck populations.

R. Bras. Zootec., 48:e20180180, 2019 


\section{Results}

Three synonymous and three non-synonymous SNP (c.52G>A, p.Glu18Lys; c.376G>A, p.Val126Ile; c.409A $>$ G, p.Thr137Ala) were detected in exon 1 of the $M C 1 R$ gene in conserved female white Tsaiya ducks by HRM and sequencing (Table 2). Next, we examined the genotype and allele frequency of the three non-synonymous SNP in white Tsaiya ducks from a conservation population and selection population. As expected, a normal genotype distribution and allele frequency of three SNP (c.52G>A, c. 376G $>A$, and c.409A $>G$ ) were observed in the conservation population (Tables 3 and 4). In contrast, the selected white Tsaiya ducks were fixed for one allele at each of the SNP $(\mathrm{P}<0.05)$ (Tables 3 and 4). Two SNP (c.52G>A and c.376G $>$ A) showed a sole homozygous genotype AA and allele frequency in white Tsaiya ducks from the selection population compared with conservation population (Table 3), whereas c.409A >G SNP showed a sole homozygous genotype GG and allele frequency in selected white Tsaiya ducks (Table 4). Taken together, AA genotype of two non-synonymous SNP loci (c.52G>A and c. $376 \mathrm{G}>\mathrm{A}$ ) and GG genotype of c.409A $>\mathrm{G}$ SNP in female white Tsaiya ducks were the advantage genotype in white plumage coloration of mule ducks.

To further characterize the effect of non-synonymous SNP loci on plumage color in mule ducks, female white Tsaiya ducks from conservation or selection population were mated by artificial insemination with pooled semen from three white Muscovy drakes. Compared with mule ducks produced by crossing conserved female white Tsaiya ducks with Muscovy drakes, two SNP (c.52G>A and c.376G>A) in mule ducks produced by crossing selected female white Tsaiya ducks with Muscovy drakes showed

Table 2 - Identified exonic polymorphisms in MC1R gene of white Tsaiya ducks

\begin{tabular}{lcc}
\hline SNP position & Amino acid change & Functional class \\
\hline c.52G $>$ A & p.Glu18Lys & Non-synonymous \\
c. $189 \mathrm{~A}>\mathrm{G}$ & p.Lys36Lys & Synonymous \\
c. $376 \mathrm{G}>\mathrm{A}$ & p.Val126Ile & Non-synonymous \\
c. $409 \mathrm{~A}>\mathrm{G}$ & p.Thr137Ala & Non-synonymous \\
c. $420 \mathrm{~T}>\mathrm{C}$ & p.Arg140Arg & Synonymous \\
c. $429 \mathrm{G}>\mathrm{C}$ & p.Thr143Thr & Synonymous
\end{tabular}

Table 3 - Genotype and allele frequency of c.52G>A and c.376G>A in MC1R gene of white Tsaiya ducks

\begin{tabular}{|c|c|c|c|c|c|c|c|}
\hline \multirow{3}{*}{ Maternal line } & \multirow{3}{*}{ Number } & \multicolumn{6}{|c|}{ c. $52 \mathrm{G}>\mathrm{A}$ and c. $376 \mathrm{G}>\mathrm{A}$} \\
\hline & & \multicolumn{3}{|c|}{ Genotype frequency } & \multicolumn{2}{|c|}{ Allele frequency } & \multirow{2}{*}{ Chi-square } \\
\hline & & GG & GA & AA & G & A & \\
\hline Conservation & 39 & $0.18_{(7)}^{a}$ & $0.38_{(15)}$ & $0.44_{(17)}$ & 0.37 & 0.63 & \\
\hline Selection & 19 & $0_{(0)}$ & $0_{(0)}$ & $1_{(19)}$ & 0 & 1 & $13.65^{\mathrm{b}}$ \\
\hline
\end{tabular}

${ }^{a}$ Number of ducks.

${ }^{b}$ Significance of Chi-square test comparing genotypic frequencies of the conservation and selection population. Chi-square in $\mathrm{df}=2$ and Probability $<0.01$, which means it must be bigger than 9.21 .

Table 4 - Genotype and allele frequency of c.409G>A in MC1R gene of white Tsaiya ducks

\begin{tabular}{|c|c|c|c|c|c|c|c|}
\hline \multirow{3}{*}{ Maternal line } & \multirow{3}{*}{ Number } & \multicolumn{6}{|c|}{ c. $409 \mathrm{G}>\mathrm{A}$} \\
\hline & & \multicolumn{3}{|c|}{ Genotype frequency } & \multicolumn{2}{|c|}{ Allele frequency } & \multirow{2}{*}{ Chi-square } \\
\hline & & GG & GA & $\mathrm{AA}$ & G & A & \\
\hline Conservation & 39 & $0.44_{(17)}^{a}$ & $0.38_{(15)}$ & $0.18_{(7)}$ & 0.63 & 0.37 & \\
\hline Selection & 19 & $1_{(19)}$ & $0_{(0)}$ & $0_{(0)}$ & 1 & 0 & $13.65^{\mathrm{b}}$ \\
\hline
\end{tabular}

${ }^{\text {a }}$ Number of ducks.

${ }^{\mathrm{b}}$ Significance of Chi-square test comparing genotypic frequencies of the conservation and selection population. Chi-square in $\mathrm{df}=2$ and Probability $<0.01$, which means it must be bigger than 9.21 . 
a genotype GA for advantage of white plumage color (grade 1-3, $\mathrm{P}<0.01$ ) (Table 5). These two SNP (c.52G>A and c.376G>A) in male Muscovy drakes were all genotype GG (data not shown), indicating that only the $\mathrm{G}$ type of allele was produced in semen. Therefore, the A allele in the two SNP (c.52G>A and c.376G $>A$ ) from female white Tsaiya ducks contributed to the determination of the white plumage color in mule ducks.

The c.409A $>$ G SNP in mule ducks produced by crossing selected female white Tsaiya ducks with Muscovy drakes showed genotype GG for the advantage of white plumage color $(\mathrm{P}<0.01)$ (Table 6). The c.409A $>$ G SNP in male Muscovy drakes was genotype GG (data not shown), implying that A allele from conserved female white Tsaiya ducks was unfavorable to white plumage color in mule ducks. Furthermore, haplotypes results showed that haplotype AAG had the highest frequency $(100 \%)$ in selected female white Tsaiya ducks compared with conserved female white Tsaiya ducks (63.3\%) and Muscovy drakes (0\%) (Table 7). However, the haplotypes GGG were restricted to the Muscovy drakes $(100 \%)$ (Table 7).

The highest frequency of haplotype GGG (50\%) was identified in mule ducks produced by crossing conserved female white Tsaiya ducks with Muscovy drakes, followed by frequencies of AAG (28.9\%) and GGA (21.1\%) (Table 7). The equal frequency of haplotype AAG and GGA was found in mule ducks produced by crossing selected female white Tsaiya ducks with Muscovy drakes (Table 7). Collectively, these results demonstrate that the maternal genotype of these three MC1R SNP identified in white Tsaiya ducks has a significant impact on the determination of black or white coat color in mule ducks.

Table 5 - Association between plumage grading and MC1R genotypes (c.52G>A and c.376G>A) in mule ducks

\begin{tabular}{|c|c|c|c|c|c|c|c|}
\hline \multirow{3}{*}{$\begin{array}{l}\text { Phenotype } \\
\text { (Plumage grading) }\end{array}$} & \multicolumn{4}{|c|}{ Conservation $^{\mathrm{a}}$} & \multicolumn{3}{|c|}{ Selection } \\
\hline & \multirow{2}{*}{ Number } & \multicolumn{2}{|c|}{ Genotype } & \multirow{2}{*}{ Chi-square } & \multirow{2}{*}{ Number } & \multicolumn{2}{|c|}{ Genotype } \\
\hline & & GG & GA & & & GG & GA \\
\hline $\begin{array}{l}\text { 1-3 } \\
\text { (Black spot on head) }\end{array}$ & 19 & 0 & 19 & & 115 & 0 & 115 \\
\hline $\begin{array}{l}\text { 4-7 } \\
\text { (Black head and a little spot on back) }\end{array}$ & 25 & 3 & 22 & & 5 & 0 & 5 \\
\hline $\begin{array}{l}\text { 8-10 } \\
\text { (Black head, black back, and black tail) }\end{array}$ & 46 & 30 & 16 & & 1 & 0 & 1 \\
\hline $\begin{array}{l}\text { 11-14 } \\
\text { (Mottled coat to pure black) }\end{array}$ & 55 & 31 & 24 & & 0 & 0 & 0 \\
\hline Total & 145 & 64 & 81 & $32.79^{b}$ & 121 & 0 & 121 \\
\hline
\end{tabular}

${ }^{a}$ Maternal line.

${ }^{\mathrm{b}}$ Significance of Chi-square test comparing plumage color grading and genotype. Chi-square in $\mathrm{df}=3$ and Probability $<0.01$, which means it must be bigger than 11.34 .

Table 6 - Association between plumage grading and MC1R genotype (c.409G>A) in mule ducks

\begin{tabular}{|c|c|c|c|c|c|c|c|}
\hline \multirow{3}{*}{$\begin{array}{l}\text { Phenotype } \\
\text { (Plumage grading) }\end{array}$} & \multicolumn{4}{|c|}{ Conservation $^{\mathrm{a}}$} & \multicolumn{3}{|c|}{ Selection } \\
\hline & \multirow{2}{*}{ Number } & \multicolumn{2}{|c|}{ Genotype } & \multirow{2}{*}{ Chi-square } & \multirow{2}{*}{ Number } & \multicolumn{2}{|c|}{ Genotype } \\
\hline & & GG & $\mathrm{GA}$ & & & GG & GA \\
\hline $\begin{array}{l}1-3 \\
\text { (Black spot on head) }\end{array}$ & 19 & 19 & 0 & & 115 & 115 & 0 \\
\hline $\begin{array}{l}\text { 4-7 } \\
\text { (Black head and a little spot on back) }\end{array}$ & 25 & 22 & 3 & & 5 & 5 & 0 \\
\hline $\begin{array}{l}\text { 8-10 } \\
\text { (Black head, black back, and black tail) }\end{array}$ & 46 & 16 & 30 & & 1 & 1 & 0 \\
\hline $\begin{array}{l}11-14 \\
\text { (Mottled coat to pure black) }\end{array}$ & 55 & 24 & 31 & & 0 & 0 & 0 \\
\hline Total & 145 & 81 & 64 & $32.79^{b}$ & 121 & 121 & 0 \\
\hline
\end{tabular}

a Maternal line.

${ }^{\mathrm{b}}$ Significance of Chi-square test comparing plumage color grading and genotype. Chi-square in $\mathrm{df}=3$ and Probability $<0.01$, which means it must be bigger than 11.34 . 
Table 7 - Reconstructed haplotypes and their frequencies for the MC1R gene in mule ducks

\begin{tabular}{lccccc}
\hline \multirow{2}{*}{ Haplotype } & \multicolumn{5}{c}{ Haplotype frequency (\%) } \\
\cline { 2 - 6 } GGG & CT & ST & MD & CM & SM \\
GAG & - & - & 100.0 & 50.0 & 50.0 \\
GAA & - & - & - & - & - \\
GGA & - & - & - & - & - \\
AAG & 36.7 & - & - & 21.1 & - \\
AGG & 63.3 & 100.0 & - & 28.9 & 50.0 \\
AGA & - & - & - & - & - \\
AAA & - & - & - & - & - \\
\hline
\end{tabular}

CT - conserved female white Tsaiya ducks; ST - selected female white Tsaiya ducks; MD - Muscovy drakes; CM - mule ducks produced by crossing conserved female white Tsaiya ducks with Muscovy drakes; SM - mule ducks produced by crossing selected female white Tsaiya ducks with Muscovy drakes.

\section{Discussion}

The specific association of SNP involved in the melanogenesis pathway and plumage color in different breeds of common ducks has been reported (Rahayu et al., 2015; Sultana et al., 2018). However, to the best of our knowledge, the present study is the first to demonstrate that the intergeneric maternal SNP of MC1R gene are associated with the plumage color of their offspring. We demonstrated that three non-synonymous SNP (c.52G>A, c.376G $>$ A, and c.409G $>$ A) identified in white Tsaiya ducks were significantly associated with the plumage color of mule ducks.

It has been reported that the white plumage color in Magelang ducks displays a predominant GG genotype of c.376G>A SNP (Rahayu et al., 2015). However, the AA genotype of c.376G >A SNP in white Kaiya and white Liancheng ducks tend to the white plumage color (Yu et al., 2013).

Consistently, we also found that white plumage color in Tsaiya ducks from a selection population displayed predominant AA genotype of c.376G $>$ A SNP. A similar association between white plumage color and AA genotype of c.52G>A SNP was also found in white Kaiya and white Liancheng ducks (Yu et al., 2013). Our result is consistent with the previous finding that AA genotype of c.52G>A SNP in white Tsaiya ducks from a selection population associates with white plumage color. Further, we demonstrated that white plumage color in mule ducks displayed a predominant GA genotype of c.52G $>$ A and c.376G $>$ A SNP. These results imply that maternal A allele from Tsaiya ducks has a strong influence on white plumage coloration in their offspring. Additionally, the GG genotype of c.409G>A SNP is associated with white plumage color in white Kaiya and white Liancheng ducks (Yu et al., 2013). In the present study, white Tsaiya ducks from a selection population and mule ducks with white plumage color also displayed predominant GG genotype of c.409G>A SNP. Currently, white Tsaiya ducks from selection populations show a low plumage color grading result (grade 1-3, data not shown) after traditional breeding. Further, their offspring produced by crossing selected female white Tsaiya ducks with Muscovy drakes also display an identical plumage color grading result (grade 1-3), while high plumage color grading was observed in mule ducks produced by crossing conserved female white Tsaiya ducks with Muscovy drakes. These findings demonstrate that maternal effect on determination of plumage color in mule ducks is greater than paternal effect.

It has been demonstrated that several plumage color mutants of ducks are produced by the combined effect of controlled breeding and selection pressure from domestication (Gong et al., 2010). Here, we also observed that other SNP associated with the plumage color of mule ducks in selected white Tsaiya ducks may be simultaneously selected by traditional breeding. For example, mule ducks with GA genotype of c.52G $>$ A and c.376G $>$ A produced by crossing conserved female white Tsaiya ducks and white Muscovy drakes displayed a dispersed plumage color grading result (grade 1-14). However, mule ducks with GA genotype of c.52G $>$ A and c.376G $>$ A produced by crossing selected female Tsaiya ducks and Muscovy drakes displayed an extremely low plumage color grading result (grade 1-3). 
In the present study, we found that these base changes of SNP in the MC1R gene sequence led to changes in the amino acid (Sultana et al., 2017). It has been reported that no significant difference is found in $M C 1 R$ mRNA expression between white and black feather bulb of ducks (Li et al., 2012), implying that these amino acid substitutions caused by non-synonymous SNP mutations might lead to structural conformational change of MC1R protein and have an effect on enhancing MC1R activity in plumage coloration. The precise mechanisms governing conformational change of MC1R protein or alteration of $\alpha$-melanocyte stimulating hormone binding activity in plumage coloration of the mule duck need to be further studied.

Mule ducks are the major meat duck breed in Taiwan. The selection of white plumage in mule ducks through breeding is in continuous demand in Taiwan due to the added economic value of such ducks. Selection of maternal lines for bleaching of mule ducks is a current breeding strategy as the mule duck is an infertile intergeneric hybrid. Over the past decade, traditional selection of maternal lines of mule duck, including Tsaiya and Pekin ducks, has successfully improved mule ducks whose white plumage is generally accepted by consumers.

In the present study, we further demonstrated that the maternal MC1R SNP genotypes in the selection population have a significant influence on white plumage coloration in mule ducks, indicating that our traditional breeding strategy for improving the plumage color of mule ducks is reliable.

\section{Conclusions}

The c.52G>A, c.376G>A, and c.409G>A amino acid substitutions in the $M C 1 R$ gene of mule ducks have a significant association with white plumage color. Our findings provide a novel insight into the relationship between maternal $M C 1 R$ gene polymorphisms and plumage color in the intergeneric hybrid ducks.

\section{Conflict of Interest}

The authors declare no conflict of interest.

\section{Author Contributions}

Conceptualization: Y.-H. Yu and M.-C. Chen. Data curation: Y.-C. Tu, Y.-H. Yu and M.-C. Chen. Formal analysis: Y.-C. Tu, Y.-H. Yu and M.-C. Chen. Funding acquisition: Y.-H. Yu and M.-C. Chen. Investigation: Y.-C. Tu, H.-H. Lee, Y.-H. Yu and M.-C. Chen. Methodology: Y.-C. Tu, Y.-H. Yu and M.-C. Chen. Project administration: Y.-H. Yu and M.-C. Chen. Resources: L.-Y. Wei, Y.-Y. Chang, H.-C. Liu, Y.-H. Yu and M.-C. Chen. Supervision: H.-C. Liu, H.-H. Lee, Y.-H. Yu and M.-C. Chen. Validation: H.-C. Liu, H.-H. Lee, Y.-H. Yu and M.-C. Chen. Writing-original draft: Y.-H. Yu and M.-C. Chen. Writing-review \& editing: Y.-H. Yu and M.-C. Chen.

\section{References}

Barrett, J. C.; Fry, B.; Maller, J. and Daly, M. J. 2005. Haploview: analysis and visualization of LD and haplotype maps. Bioinformatics 21:263-265. https://doi.org/10.1093/bioinformatics/bth457

Everts, R. E.; Rothuizen, J. and van Oost, B. A. 2000. Identification of a premature stop codon in the melanocyte-stimulating hormone receptor gene (MC1R) in Labrador and Golden retrievers with yellow coat colour. Animal Genetics 31:194-199. https://doi.org/10.1046/j.1365-2052.2000.00639.x

Gong, Y.; Yang, Q.; Li, S.; Feng, Y.; Gao, C.; Tu, G. and Peng, X. 2010. Grey plumage colouration in the duck is genetically determined by the alleles on two different, interacting loci. Animal Genetics 41:105-108. https://doi.org/10.1111/j.1365-2052.2009.01967.x

Hoque, M. R.; Jin, S.; Heo, K. N.; Kang, B. S.; Jo, C. and Lee, J. H. 2013. Investigation of MC1R SNPs and their relationships with plumage colors in Korean native chicken. Asian-Australasian Journal of Animal Sciences 26:625-629. https://doi.org/10.5713/ajas.2012.12581

R. Bras. Zootec., 48:e20180180, 2019 
Kerje, S.; Lind, J.; Schütz, K.; Jensen, P. and Andersson, L. 2003. Melanocortin 1-receptor $(M C 1 R)$ mutations are associated with plumage colour in chicken. Animal Genetics 34:241-248. https://doi.org/10.1046/j.1365-2052.2003.00991.x

Klungland, H.; Våge, D. I.; Gomez-Raya, L.; Adalsteinsson, S. and Lien, S. 1995. The role of melanocyte-stimulating hormone (MSH) receptor in bovine coat color determination. Mammalian Genome 6:636-639. https://doi.org/10.1007/ BF00352371

Lee, S. R. and Kang, C. L. 1997. Improvement on percentage of white plumage in mule ducks. Journal of Taiwan Livestock Research 30:293-299.

Li, S.; Wang, C.; Yu, W.; Zhao, S. and Gong, Y. 2012. Identification of genes related to white and black plumage formation by RNA-Seq from white and black feather bulbs in ducks. PLoS One 7(5):e36592. https://doi.org/10.1371/journal. pone.0036592

Mundy, N. I. 2005. A window on the genetics of evolution: MC1R and plumage colouration in birds. Proceedings Biological Sciences 272:1633-1640. https://doi.org/10.1098/rspb.2005.3107

Marklund, L.; Moller, M. J.; Sandberg, K. and Andersson, L. 1996. A missense mutation in the gene for melanocytestimulating hormone receptor $(M C 1 R)$ is associated with the chestnut coat color in horses. Mammalian Genome 7:895-899. https://doi.org/10.1007/s003359900264

Newton, J. M.; Wilkie, A. L.; He, L.; Jordan, S. A.; Metallinos, D. L.; Holmes, N. G.; Jackson, I. J. and Barsh, G. S. 2000. Melanocortin 1 receptor variation in the domestic dog. Mammalian Genome 11:24-30. https://doi.org/10.1007/s003350010005

Ollmann, M. M.; Lamoreux, M. L.; Wilson, B. D. and Barsh, G. S. 1998. Interaction of Agouti protein with the melanocortin 1 receptor in vitro and in vivo. Genes \& Development 12:316-330. https://doi.org/10.1101/gad.12.3.316

Prota, G. 1980. Recent advances in the chemistry of melanogenesis in mammals. Journal of Investigative Dermatology 75:122-127. https://doi.org/10.1111/1523-1747.ep12521344

Ran, J. S.; You, X. Y.; Jin, J.; Zhou, Y. G.; Wang, Y.; Lan, D.; Ren, P. and Liu, Y. P. 2016. The relationship between MC1R mutation and plumage color variation in pigeons. BioMed Research International 2016:3059756. https://doi.org/10.1155/2016/3059756

Rahayu, A.; Purwantini, D.; Maharani, D. and Hartatik, T. 2015. Single nucleotide polymorphisms identification and genotyping analysis of Melanocortin 1 Receptor gene in various plumage colours Magelang ducks. International Journal of Poultry Science 14:207-212. https://doi.org/10.3923/ijps.2015.207.212

Schiöth, H. B.; Raudsepp, T.; Ringholm, A.; Fredriksson, R.; Takeuchi, S.; Larhammar, D. and Chowdhary, B. P. 2003. Remarkable synteny conservation of melanocortin receptors in chicken, human, and other vertebrates. Genomics 81:504-509. https://doi.org/10.1016/S0888-7543(03)00028-4

Sultana, H.; Seo, D. W.; Park, H. B.; Choi, N. R.; Hoque, M. R.; Bhuiyan, M. S. A.; Heo, K. N.; Lee, S. H. and Lee, J. H. 2017. Identification of MC1R SNPs and their association with plumage colors in Asian duck. The Journal of Poultry Science 54:111-120. https://doi.org/10.2141/jpsa.0160047

Sultana, H.; Seo, D.; Choi, N. R.; Bhuiyan, M. S. A.; Lee, S. H.; Heo, K. N. and Lee, J. H. 2018. Identification of polymorphisms in MITF and DCT genes and their associations with plumage colors in Asian duck breeds. Asian-Australasian Journal of Animal Sciences 31:180-188. https://doi.org/10.5713/ajas.17.0298

Yu, W.; Wang, C.; Xin, Q.; Li, S.; Feng, Y.; Peng, X. and Gong, Y. 2013. Non-synonymous SNPs in MC1R gene are associated with the extended black variant in domestic ducks (Anas platyrhynchos). Animal Genetics 44:214-216. https://doi.org/10.1111/j.1365-2052.2012.02377.x

Zhang, N. N.; Hu, J. W.; Liu, H. H.; Xu, H. Y.; He, H. and Li, L. 2015. SNPs in the 5'-regulatory region of the tyrosinase gene do not affect plumage color in ducks (Anas platyrhynchos). Genetics and Molecular Research 14:18623-18628. https://doi.org/10.4238/2015.December.28.11 